\title{
Characterization of the progestin receptors in the human TE85 and murine MC3T3-E1 osteoblast-like cell lines
}

\author{
J W Gunnet, K Granger, E Cryan and K T Demarest
}

The R W Johnson Pharmaceutical Research Institute, Route 202, Raritan, New Jersey 08869, USA

(Requests for offprints should be addressed to J W Gunnet)

\begin{abstract}
Progestins are believed to exert positive effects on bone density through receptors located in osteoblasts. In the present studies, the binding characteristics and regulation of the progestin receptors in two osteoblast-like cell lines were compared with those in human breast lines. Human TE85 and murine MC3T3-E1 osteoblast-like cells contain a single, high-affinity progestin binding site whose affinity and concentration are lower than in human breast cells. The osteoblastic progestin binding sites showed the expected steroid specificity and associated with the cell nuclei when occupied by ligand. The progestin receptors in osteoblastic cells also had sedimentation coefficients similar to those receptors in breast cells. The regulation of the progestin receptor in the osteoblast-like cells was explored by treating them with estradiol. In contrast to the large, rapid change seen in the breast cells, the progestin receptor levels in the MC3T3-E1 cells showed only a
\end{abstract}

small, delayed up-regulation with estradiol treatment. The progestin receptor number in the TE85 cells was unaffected by estradiol. Down-regulation of the progestin receptors was explored by treating the cells with the progestin, norethindrone (NET). NET administration produced a rapid drop in progestin binding sites in the breast cells and a smaller, more gradual decline in MC3T3-E1 progestin binding. While the maximal decrease in receptor number occurred within $24 \mathrm{~h}$ in the breast cells, the receptor number was still continuing to fall after $72 \mathrm{~h}$ in the MC3T3-E1 cells. The data presented here demonstrate that both human and murine osteoblastlike cells contain a functional progestin receptor whose binding characteristics and regulation are similar, but not identical, to those receptors in other progestin target tissues such as the breast.

Journal of Endocrinology (1999) 163, 139-147

\section{Introduction}

Progestins are frequently prescribed to postmenopausal women in combination with an estrogen for treating osteoporosis (Prior 1990, Sturdee 1997). The estrogenic component in hormone replacement therapy (HRT) exerts a well-known positive effect on bone mass. The primary function of the progestin in HRT has been to counter the unwanted estrogen-induced proliferation of the uterine endometrium. However, progestins can also exert positive effects on bone. In postmenopausal women, the resorption of bone can be reduced (Abdalla et al. 1985, Gallagher et al. 1991, McNeeley et al. 1991) and the formation of new bone increased by progestins (Christiansen et al. 1985, Horowitz et al. 1987).

The ability of progestins to promote bone formation may be due to their ability to act directly upon osteoblasts. In vitro, progestins stimulate the proliferation of human osteosarcoma cells and normal human osteoblasts obtained from bone specimens (Tremollieres et al. 1992, Lau et al. 1994, Verhaar et al. 1994). Progestins can also stimulate the differentiation and the bone-forming activity of osteoblasts (Lau et al. 1994, Verhaar et al. 1994, Ishida et al.
1996). The effects of progestins are believed to be mediated through nuclear steroid receptors. Progestin receptors have been identified in osteoblasts and osteoblast-like osteosarcoma cells with a number of techniques including radioligand binding (Eriksen et al. 1988, Etienne et al. 1990, Slootweg et al. 1992, Wei et al. 1993), receptor mRNA detection following reverse transcription PCR (Wei et al. 1993, MacNamara et al. 1995, MacNamara \& Loughrey 1998), immunoassay (Pensler et al. 1990, Orwoll et al. 1991) and immunocytochemistry (Penslar et al. 1990, MacNamara et al. 1995). However, neither specific binding nor immunocytochemical staining for the progestin receptor is always detectable in osteoblasts (Colston et al. 1989, Pensler et al. 1990, Orwoll et al. 1991, Wei et al. 1993). Common to all these studies is the conclusion that the concentrations of the progestin receptor in osteoblastic cells are low, thus making studies of this receptor difficult. The presence of the progestin receptor in osteoblasts has been well demonstrated but many of the basic characteristics of these receptors are still unclear.

The goal of the present studies was to better describe the characteristics and regulation of the progestin receptor in osteoblastic cells. In these studies, the progestin 
receptors in two commonly used osteoblastic cell lines, the human TE85 osteosarcoma cells and the murine MC3T3-E1 osteoblast-like cells were compared with those in human breast cells.

\section{Materials and Methods}

\section{Cell culture}

Two human breast carcinoma cell lines were used in these studies. T47D breast cells were obtained from the American Type Culture Collection (Rockville, MD, USA) and ZR75 breast cells from Dr Rosalyn Blumenthal, Center for Molecular Medicine and Immunology (Newark, NJ, USA). Both breast cell lines were maintained in RPMI medium (Gibco Laboratories, Grand Island, NY, USA) supplemented with $10 \%$ bovine calf serum (BCS, Hyclone Laboratories, Logan, UT, USA). Human osteosarcoma cells (TE85) were obtained from Dr William Lau, J L Pettis Veterans Hospital (Loma Linda, CA, USA). Mouse osteoblast-like cells (MC3T3-E1) were obtained from Dr Tom Einhorn, Mount Sinai Hospital (New York, NY, USA). TE85 and MC3T3-E1 cells were grown in DMEM medium (Gibco Laboratories) supplemented with $10 \%$ BCS. All cells were grown under a 5\% $\mathrm{CO}_{2}$ atmosphere at $37^{\circ} \mathrm{C}$ with no antibiotics.

In preparation for receptor assays, culture media were replaced with RPMI or DMEM media containing 10\% charcoal-stripped fetal calf serum (CSS) 24 h before cell harvest. Cells were harvested by trypsinization and washed with Hanks' balanced salt solution (HBSS; Gibco Laboratories). Cell number was determined following the harvesting of each experimental treatment group. Cell viability were determined by trypan blue exclusion. The cells were homogenized on ice in TEG assay buffer (0.01 M Tris, $1 \mathrm{mM}$ EDTA, 0.01 M molybdic acid, 10\% glycerol, $\mathrm{pH} 7 \cdot 4$ ) for progestin receptor assays or TEG with $1 \mathrm{mM}$ dithiothreitol for estrogen receptor assays. The homogenate was centrifuged for $12 \mathrm{~min}$ at $541000 \mathrm{~g}$ at $4{ }^{\circ} \mathrm{C}$ in a Beckman (Fullerton, CA, USA) TL-100 ultracentrifuge. The supernatant containing the cell cytosol and/or the nuclear pellet was diluted in the appropriate buffer according to the number of live cells homogenized.

\section{Progestin and estrogen receptor binding assays}

For saturation and competition progestin receptor studies, binding was measured in tubes containing the cytosol from $1 \times 10^{6}$ breast (T47D and ZR75) cells, $3 \times 10^{6}$ MC3T3-E1 cells or $4-5 \times 10^{6}$ TE85 cells according to the methods of Clark et al. (1989). Cell cytosol (200 $\mu \mathrm{l})$ was incubated overnight at $4{ }^{\circ} \mathrm{C}$ with $\left[{ }^{3} \mathrm{H}\right] \mathrm{R} 5020$ (specific activity $86-87 \mathrm{Ci} / \mathrm{mmol}$; NEN, Wilmington, DE, USA). Saturation analyses of progestin binding in cell cytosols were conducted using $0 \cdot 1-20 \mathrm{nM}$ concentrations of $\left[{ }^{3} \mathrm{H}\right] \mathrm{R} 5020$. Non-specific binding was measured in the presence of 100-fold excess non-radioactive R5020. Receptor specificity was determined in competition binding studies using $10 \mathrm{nM}\left[{ }^{3} \mathrm{H}\right] \mathrm{R} 5020$ and $1 \mu \mathrm{M}$ of various steroids. An aliquot of the $\left[{ }^{3} \mathrm{H}\right] \mathrm{R} 5020-$ bound fraction was transferred into vials for scintillation counting. The protein content of the cytosol preparations was determined using a protein measurement kit obtained from Bio-Rad Laboratories (Richmond, VA, USA). Measurement of nuclear-bound progestin receptors was performed by incubating a known number of live intact cells with $10 \mathrm{nM}\left[{ }^{3} \mathrm{H}\right] \mathrm{R} 5020$ in the presence or absence of $1 \mu \mathrm{M}$ non-radioactive R5020 for $1 \mathrm{~h}$. The cells were then washed twice with HBSS, homogenized and centrifuged. The nuclear-bound $\left.{ }^{3} \mathrm{H}\right] \mathrm{R} 5020$ was solubilized in $1 \mathrm{ml}$ ethanol and counted. To measure changes in the concentration of progestin receptors following progestin treatment, the cytosolic and nuclear fractions of the cells were incubated overnight with $10 \mathrm{nM}\left[{ }^{3} \mathrm{H}\right] \mathrm{R} 5020$ to allow ligand exchange (Clark et al. 1989). In some studies, the binding of ${ }^{125}$ I-labelled vinyl 19-nortestosterone (VNT) (NEN; specific activity $367 \mathrm{Ci} / \mathrm{mmol}$ ) was used to quantitate the number of progestin binding sites. For these studies, $10 \mathrm{nM}{ }^{125} \mathrm{I}-\mathrm{VNT}$ was used to determine total binding with $1 \mu \mathrm{M}$ norethindrone (NET) added for measuring non-specific binding. Bound radioactivity was counted in a gamma counter. Saturation binding studies for estrogen receptors in MC3T3-E1 cells were performed using ${ }^{125} \mathrm{I}-17 \beta$-estradiol (NEN; specific activity $220 \mathrm{Ci} /$ mmol) at concentrations of $0 \cdot 1-20 \mathrm{nM}$. Each assay tube contained the cytosol of $12.5 \times 10^{6}$ live cells. Nonspecific binding was measured in tubes containing diethylstilbestrol at a concentration 100-fold greater than that of tracer.

The analyses of saturation binding data were conducted using RECEPTORFIT computer software (Lundon Software, Chagrin Falls, OH, USA), which performs weighted non-linear least-squares regression analysis as described by Feldman (1972). Data were graphed according to the method of Scatchard (1949). Saturation binding experiments were replicated three to five times.

\section{Sucrose density gradients}

Cytosols from TE85 osteoblastic cells and ZR75 breast cells were fractionated through sucrose density gradients. Cell cytosols were prepared by the standard procedure and $200 \mu \mathrm{l}$ were layered on a $4.7 \mathrm{ml}$ sucrose density gradient. Gradients of $10-30 \%$ sucrose were poured into Beckman Optiseal polyallomer tubes using a gradient maker. Tubes were chilled to $4{ }^{\circ} \mathrm{C}$ before the sample was loaded. The tubes were sealed, placed in a Beckman VTi 90 vertical tube rotor and run at $509650 \mathrm{~g}$ for approximately $1 \mathrm{~h}$ 45 min in a Beckman XL-90 ultracentrifuge. Thirty-six fractions of approximately $200 \mu \mathrm{l}$ each (3 drops/fraction) were collected from each gradient tube. Fractions 
were collected into glass test tubes containing $1 \mathrm{nM}$ ${ }^{125}$ I-VNT and either assay buffer or NET $(100 \mathrm{nM})$. The tubes were then incubated overnight at $4{ }^{\circ} \mathrm{C}$. Bound and free radioligand were separated by dextran-coated charcoal absorption and bound radioligand counted in a gamma counter. The migration of BSA and catalase was measured in parallel gradients in order to determine sedimentation coefficients of the ${ }^{125} \mathrm{I}-\mathrm{VNT}$ binding sites.

Measurement of in vitro alkaline phosphatase activity

TE85 cells were grown in 24-well plates (Corning, Corning, NY, USA) under standard culture conditions. Twenty-four hours after seeding the plates (24000 cells/ well), the medium was replaced with DMEM-CSS. The following day the medium was again replaced with DMEM- $0 \cdot 2 \%$ fetal bovine serum containing vehicle $(0 \cdot 1 \%$ ethanol) or rest steroid. Each treatment group consisted of six wells. After incubation for $72 \mathrm{~h}$, the cells were washed with HBSS and each well received $0.5 \mathrm{ml}$ Triton-X (1\% in distilled water) to lyse the cells. The alkaline phosphatase activity in the lysate was quantitated by measuring the hydrolysis of paranitrophenyl phosphate $(10 \mathrm{nM})$ with reagents from Sigma Chemical Co. (St Louis, MO, USA). Alkaline phosphatase activity was normalized for the protein content in the cell lysates. Statistical comparisons were performed with Dunnett's one-tailed $t$-test.

\section{Results}

Saturation analyses with $\left.P^{3} H\right] R 5020$

The binding of $\left[{ }^{3} \mathrm{H}\right] \mathrm{R} 5020$ was measured in cytosol preparations from murine MC3T3-E1 osteoblast-like cells and human TE85 osteoblast-like cells. As a comparator, similar data were generated with the human T47D breast cells, a line in which much of the physical characterization of the human progestin receptor was originally done (Horwitz et al. 1985). The cytosols of the osteoblast-like cell lines were found to contain a single, high-affinity, saturable binding site for R5020. Representative Scatchard plots and saturation binding graphs are shown in Fig. 1. The dissociation constants $\left(K_{\mathrm{d}}\right)$ and binding site concentrations derived from saturation studies are in Table 1.

While both the MC3T3-E1 and TE85 osteoblast-like cells show high-affinity binding sites for R5020, the affinity of these sites appears lower than for those sites in the T47D breast cells. The R5020 $K_{\mathrm{d}}$ reported here for the $\mathrm{T} 47 \mathrm{D}$ progestin receptor is similar to the binding constant for the progestin receptor in human uterus, prostate and breast (Namkung \& Petra 1981, Schneider et al. 1984, Van der Walt et al. 1986). These binding affinities and receptor concentrations for the TE85 and MC3T3-E1 cells are similar to those reported for other human osteosarcoma lines (Etienne et al. 1990, Slootweg
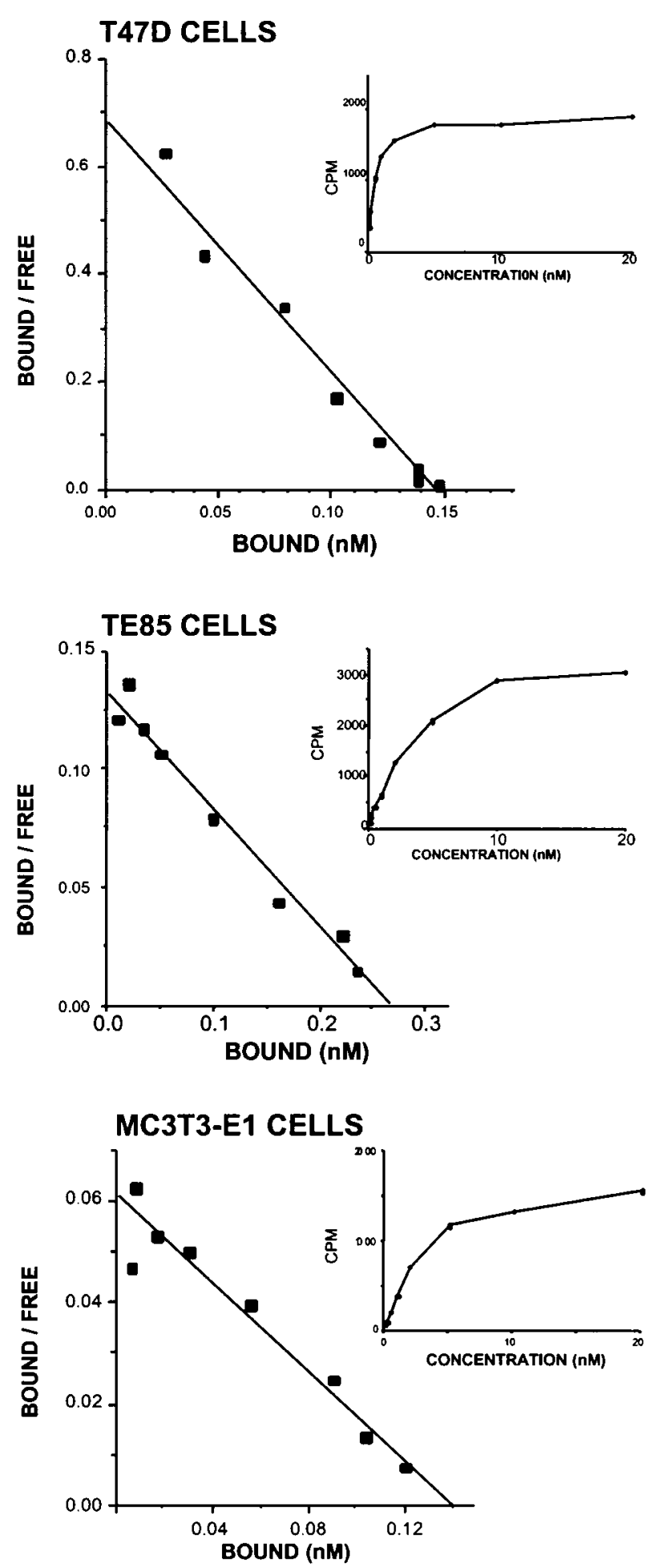

Figure 1 Scatchard plots and saturation graphs of $\left[{ }^{3} \mathrm{H}\right] \mathrm{R} 5020$ binding in T47D breast cells, TE85 osteoblast-like cells and MC3T3-E1 osteoblast-like cells. 
Table 1 Dissociation constants $\left(K_{\mathrm{d}}\right)$ and concentrations of $\left[{ }^{3} \mathrm{H}\right] \mathrm{R} 5020$ binding sites in the cytosol of breast and osteoblast-like cells. Values are means \pm S.E.M. of three to five replicate studies

\begin{tabular}{|c|c|c|c|}
\hline & $\begin{array}{l}\text { Binding site } \\
K_{d}(n M)\end{array}$ & $\begin{array}{l}\text { Binding site } \\
\text { concentration } \\
\text { (fmol/mg protein) }\end{array}$ & $\begin{array}{l}\text { Number of binding } \\
\text { sites per cell }\end{array}$ \\
\hline \multicolumn{4}{|l|}{ Cell type } \\
\hline T47D breast cells & $0 \cdot 20 \pm 0 \cdot 05$ & $3296 \pm 947$ & $32947 \pm 14517$ \\
\hline MC3T3-E1 osteoblast-like cells & $3 \cdot 40 \pm 1 \cdot 01$ & $241 \pm 50$ & $11133 \pm 2439$ \\
\hline TE85 osteoblast-like cells & $4.60 \pm 1.59$ & $244 \pm 59$ & $8546 \pm 1669$ \\
\hline
\end{tabular}

et al. 1992, Wei et al. 1993). When R5020 binding is expressed in terms of cytosolic protein concentration, the numbers of TE85 and MC3T3-E1 R5020 binding sites are less than one-tenth of that found in the T47D breast cells. However, when expressed on a per cell basis, the osteoblast-like cells contain approximately one-fourth to one-third as many receptors as the T47D cells. The osteoblastic cells are much larger than the T47D cells and so comparing their relative receptor numbers based on cytosolic protein may be less informative than comparing their receptor concentrations on a per cell basis.

\section{Progestin receptor binding specificity}

The steroid specificity of the TE85 and MC3T3-E1 progestin binding sites was tested with several steroids. The two synthetic progestins, NET and levonorgestrel, inhibited all specific R5020 binding as shown in Table 2. Neither $17 \beta$-estradiol nor dexamethasone competed for any R5020 binding. The androgen, dihydrotestosterone showed some competition for the R5020 binding sites in both osteoblast-like cell lines.

\section{PH]R5020 binding to the nuclei of TE85 osteoblast-like cells}

The binding of a progestin to its receptor within the cell induces receptor activation and gives the receptor the capability to bind to DNA (Truss \& Beato 1993). To further demonstrate the presence of progestin receptors in TE85 cells, the ability of the receptor to bind to the cell

Table 2 Inhibition (\%) of total $\left.{ }^{3} \mathrm{H}\right] \mathrm{R} 5020$ binding $(10 \mathrm{nM})$ in the cytosol of MC3T3-E1 and TE85 cells by various steroids $(1 \mathrm{mM})$

\begin{tabular}{lrrr} 
& \multicolumn{2}{c}{ MC3T3-E1 cells } & TE85 cells \\
\cline { 2 - 2 } Steroid & 100 & \\
R5020 & 100 & 100 \\
NET & 100 & 100 \\
Levonorgestrel & 0 & 100 \\
17ß-estradiol & 0 & 0 \\
Dexamethasone & 60 & 0 \\
Dihydrotestosterone & & 24 \\
\end{tabular}

nucleus was tested. After incubation with $\left[{ }^{3} \mathrm{H}\right] \mathrm{R} 5020$ $(10 \mathrm{nM})$ for $1 \mathrm{~h}$ at either $0{ }^{\circ} \mathrm{C}$ or $37^{\circ} \mathrm{C}$, TE85 cells were homogenized and the nuclei collected. In those cells incubated at $0{ }^{\circ} \mathrm{C}$, the amount of $\left[{ }^{3} \mathrm{H}\right] \mathrm{R} 5020$ associated with the nuclear pellet was equivalent to approximately 202 receptors per nucleus. When incubated at $37^{\circ} \mathrm{C}$ the quantity of $\left[{ }^{3} \mathrm{H}\right] \mathrm{R} 5020$ bound to the nuclear pellet increased to an amount equivalent to 1043 receptors per nucleus.

\section{Identification of the progestin receptor in sucrose density gradients}

One method of comparing steroid receptors has been to study their migration through sucrose density gradients. The migration of the progestin binding sites in cytosol from TE85 cells was determined by measuring progestin binding in sucrose gradient fractions. Parallel studies were performed using cytosol from ZR75 cells. Like the T47D cells, the ZR75 cells are another human breast line containing well-characterized progestin receptors (Allegra et al. 1981, Van den Berg et al. 1990). The ZR75 cells, however, contain a lower concentration of progestin receptors making them the better comparator for the osteoblastic cells in these gradient studies.

To more easily quantitate progestin binding in the gradient fractions, ${ }^{125} \mathrm{I}-\mathrm{VNT}$ was used as the radioligand in place of $\left[{ }^{3} \mathrm{H}\right] \mathrm{R} 5020$. $\left.{ }^{3} \mathrm{H}\right] \mathrm{R} 5020$ is the most commonly used radioligand but does not have sufficient specific activity for the present studies. ${ }^{125} \mathrm{I}-\mathrm{VNT}$ is a specific, high-affinity ligand for the progestin receptor (Hochberg et al. 1985) with a specific activity more than four times greater than that of $\left[{ }^{3} \mathrm{H}\right] \mathrm{R} 5020$. As shown in Fig. 2, the progestin binding sites in the cytosol of the ZR75 and TE85 cells show similar migration in sucrose density gradients. The sedimentation coefficients were calculated to be $8 \cdot 8 \pm 0 \cdot 4$ (mean \pm S.E.M. of 5 gradients) and $8 \cdot 9 \pm 0.2$ (mean \pm S.E.M. of 6 gradients) for the ZR75 and TE85 receptors respectively. These values agree with other reports in which the uterine progestin receptor was found to have sedimentation coefficients ranging between 7 and 9.5 (Faber et al. 1973, Tai et al. 1986, Renoir et al. 1990). NET displaced the majority of the bound ${ }^{125}$ I-VNT from the gradient fractions of both cell lines. 


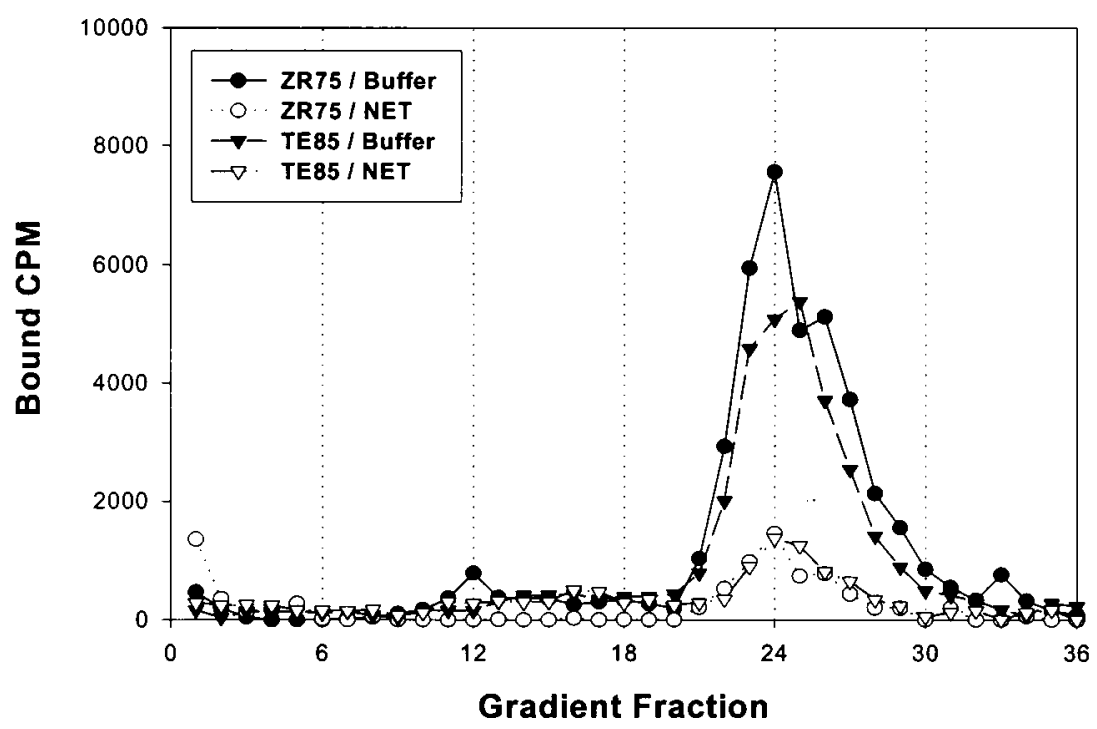

Figure 2 Binding of ${ }^{125}$ I-VNT to sucrose gradient fractions of cytosol from ZR75 and TE85 cells. Gradient fractions were incubated overnight with $1 \mathrm{nM}{ }^{125} \mathrm{I}$-VNT and assay buffer or NET (100 nM) before separation of bound and free tracer.

Steroid regulation of progestin receptors in osteoblast-like cells

In progestin-responsive tissues, progestin receptor number is under positive regulation by estradiol. To explore the regulation of progestin receptors in osteoblasts, the effects of estradiol on progestin receptor number in the TE85 and MC3T3-E1 cells were determined. The effects of estradiol in the osteoblast-like cells were compared with that in human ZR75 human breast cells. ZR75 breast cells contain functional estrogen receptors which can regulate progestin receptors (Allegra et al. 1981, Van den Berg et al. 1990). Cytosolic progestin receptors in the ZR75 cells were increased by $17 \beta$-estradiol within $24 \mathrm{~h}$ and reached their maximum by $72 \mathrm{~h}$ (Fig. 3). In contrast, estradiol treatment had no effect on cytosolic progestin receptor numbers in TE85 cells and a relatively modest effect on MC3T3-E1 receptor number. Only after $72 \mathrm{~h}$ of treatment did estradiol affect MC3T3-E1 receptor number, increasing it to $147 \%$ of control.

When under constant exposure to ligand, progestin receptors undergo down-regulation and their number drops accordingly. The effects of NET $(1 \mathrm{nM})$ on progestin binding were followed over the course of $72 \mathrm{~h}$ in ZR75 and MC3T3-E1 cells (Fig. 4). NET caused a dramatic decline in ${ }^{125}$ I-VNT binding in the ZR75 cells, dropping to $10 \%$ of control levels within $24 \mathrm{~h}$. The number of progestin binding sites remained at these low levels through $72 \mathrm{~h}$. Progestin binding also decreased in MC3T3-E1 cells during NET treatment but the decline was more gradual and reached a minimum of $16 \%$ of control levels only after $72 \mathrm{~h}$.
When compared with the effects seen in the ZR75 cells, the small osteoblastic cell responses following estradiol treatment may reflect cell-specific differences in progestin receptor regulation or may simply result from a low number of estrogen receptors within the osteoblastlike cells. Estrogen receptors have been found in MC3T3-E1 cells and 17 $\beta$-estradiol will stimulate the proliferation of these cells (Kanatani et al. 1991, Masuyama et al. 1992). To confirm the presence of and quantitate the estrogen receptors in the MC3T3-E1 cells used in the present study, binding studies were performed using $\left.{ }^{125} \mathrm{I}\right] 17 \beta$-estradiol. Saturation analyses showed that the MC3T3-E1 cells contained a single, high-affinity binding site for $17 \beta$-estradiol numbering $3976 \pm 1837$ per cell with a $K_{\mathrm{d}}$ of $0.72 \pm 0.09 \mathrm{nM}$ (mean \pm s.E.M. of three assays). The receptor binding affinity and receptor concentration agree with previous studies with the MC3T3-E1 cells (Masuyama et al. 1992) and are similar to those reported for other osteoblast-like lines including the TE85 cell line (Komm et al. 1988, Benz et al. 1991).

\section{Progestin stimulation of osteoblast differentiation}

Alkaline phosphatase is a marker of osteoblast differentiation and an index of osteoblast activity. The ability of progestins to affect TE85 osteoblast activity was tested by measuring cellular alkaline phosphatase activity after treatment with progestational, androgenic and estrogenic steroids (Table 3). Only treatment with the three progestins increased alkaline phosphatase activity in the TE85 cells while neither cyproterone acetate, dihydrotestosterone nor estradiol had any effect. 


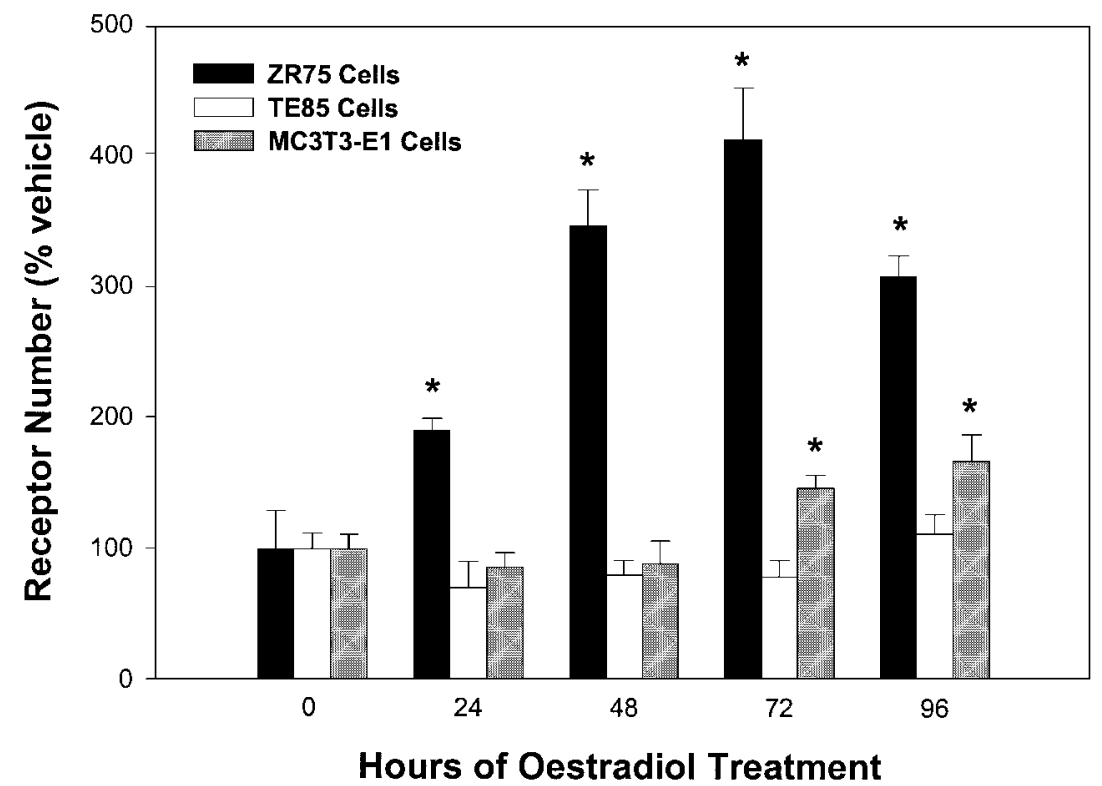

Figure 3 Change in progestin receptor number in ZR75, TE85 and MC3T3-E1 cells after 24-96 h of treatment with $17 \beta$-estradiol $(1 \mathrm{nM})$. Columns represent the mean number of ${ }^{125}$ I-VNT binding sites from three measurements $( \pm$ S.E.M.) normalized for cell number. ${ }^{\star} P<0 \cdot 05$ versus vehicle-treated cells.

\section{Discussion}

The goal of the present studies was to better characterize the progestin receptors in osteoblasts. There exists sufficient evidence from other laboratories to prove the existence of such receptors but little has been done to study and compare the regulation of these receptors. Progestin receptors have been localized to osteoblasts by RIA, immunocytochemistry and radioligand binding. The

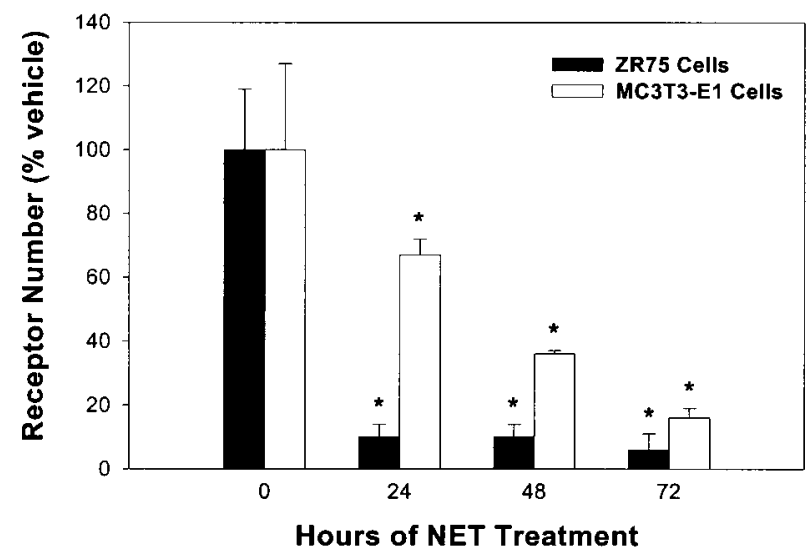

Figure 4 Change in progestin receptor number in ZR75 and MC3T3-E1 cells after 24-72 h of treatment with NET (1 nM). Columns represent the mean number of ${ }^{125}$ I-VNT binding sites from three measurements ( \pm S.E.M.) expressed as a percent of the number of binding sites found in vehicle-treated cells. ${ }^{*} P<0 \cdot 05$ versus vehicle-treated cells. presence of the progestin receptor in osteoblastic cells has been validated through the use of PCR and Northern blot analysis (Wei et al. 1993, MacNamara et al. 1995, MacNamara \& Loughrey 1998). However, quantitating changes in the concentrations of the receptor or its message have been difficult due to their low number per cell. In fact, in some experiments the receptor was not detected in certain osteoblast cell lines (Colston et al. 1989, Pensler et al. 1990, Orwoll et al. 1991, Wei et al. 1993). To perform the present studies, we employed large numbers of cells from two different osteoblastic lines to ensure a reasonable signal-to-noise ratio for the binding assays and also used a radioligand with a higher specific activity than has been

Table 3 Alkaline phophatase activity in TE85 cells after $72 \mathrm{~h}$ of treatment with various steroids $(100 \mathrm{nM})$. Values are means alkaline phosphatase activity measured in six wells ( \pm S.E.M.) expressed as a percent of the enzyme activity measured in vehicle-treated cells

Vehicle

NET

Levonorgestrel

Medroxyprogesterone acetate

Alkaline phosphatase activity (\% vehicle control)

Cyproterone acetate

Dihydrotestosterone

$17 \beta$-estradiol

$100 \pm 4$

$147 \pm 3^{*}$

$121 \pm 2^{*}$

$138 \pm 7^{*}$

$102 \pm 4$

$114 \pm 9$

$106 \pm 10$

${ }^{*} P<0 \cdot 05$ versus vehicle-treated cells. 
used in the past. The data presented here demonstrate that osteoblast-like cells contain a functional progestin receptor. These receptors are like progestin receptors in all tissues in that they selectively bind progestins, become associated with the cell nuclei when occupied and have a sedimentation coefficient identical to that of breast cell receptors. However, the progestin receptors in osteoblastic cells differ from that in breast cells in terms of their binding affinity and regulation.

In our initial experiments, the binding of R5020 was quantitated in T47D breast cells and the two osteoblastlike lines, the TE85 and MC3T3-E1 cells. A single, high-affinity binding site was found in each cell type. Interestingly, the affinity of the receptors within the T47D breast cells was greater than the affinities in the osteoblastic cells. The values reported here for R5020 binding in the T47D, TE85 and MC3T3-E1 cells all fall within the general range of reported progestin receptor affinities. However, given that the present values were generated in concurrent experiments using the same procedures in the same laboratory, these differences are meaningful and do suggest differences in progestin binding in breast and osteoblastic cells. Tissue differences in the binding affinities of progestin and glucocorticoid receptors have been previously reported (Al-Khouri \& Greenstein 1985, Ojasoo et al. 1988). The difference in progestin receptor affinity in breast and osteoblastic cells does not help explain how some progestins can stimulate the proliferation and activity of osteoblast-like cells at concentrations below those necessary to elicit a response in other progestin target tissues (Tremollieres et al. 1992, Lau et al. 1994, Verhaar et al. 1994). It is counter intuitive to imagine that a receptor with a higher $K_{\mathrm{d}}$ would allow a cell to respond to lower concentrations of hormone than other cells containing a receptor whose ligand affinity is greater. In addition to binding affinity, another notable difference between the T47D cells and the two osteoblastic cell lines is the concentration of progestin binding sites. This comparison had been made in earlier studies that had found even greater differences between the number of R5020 binding sites in breast and osteoblastic cells (Wei et al. 1993).

As anticipated, estrogen treatment increased the number of progestin binding sites in the breast and osteoblast-like cells. However, the increases in progestin binding sites in the ZR75 breast cells occurred more quickly and were of greater magnitude than that seen in the TE85 or MC3T3-E1 cells. The inability of estradiol to affect progestin binding sites in the TE85 cells could be due to a species difference between these cells and the murine MC3T3-E1 cells. This difference is minor, however, compared with that observed between breast and osteoblastic cell types. The apparent tissue differences may be due to several factors. M3T3-E1 cells contain fewer estrogen receptors than have been found in the ZR75 breast cells (Lippman et al. 1981) and this may make these osteoblastic cells less responsive to estradiol. The culture conditions of the MC3T3-E1 cells may also have reduced their estrogen responsiveness. Osteosarcoma cells transfected with the estrogen receptor will express a greater number of those receptors when the cells are maintained in sub-confluent culture conditions (Migliaccio et al. 1993). In the present experiments, both the TE85 and the MC3T3-E1 cells reached confluency at some time during the estradiol treatments. The confluency of these cells could have not only reduced their number of estrogen receptors but may also have blunted the stimulatory effects of estradiol on progestin receptor levels. Osteoblasts and osteoblast-like cells have shown a wide range of responsiveness to estrogens, which has not always correlated with the estrogen receptor number. Human fetal osteoblastic cells transfected with the estrogen receptor show a $2 \cdot 5$-fold increase in progestin binding sites after estradiol addition (Harris et al. 1995). Yet, in similar experiments, human osteosarcoma HTB-96 cells transfected with the human estrogen receptor show no progestin receptor induction or increase in alkaline phosphatase activity after estradiol treatment (Watts et al. 1989).

Cell differences in progestin receptor regulation were also apparent when NET-induced receptor downregulation was measured. Within the first $24 \mathrm{~h}$ of treatment, NET induced a rapid loss in cytosolic progestin binding sites in the ZR75 cells. Only after $72 \mathrm{~h}$ of treatment was a loss of similar magnitude seen in the MC3T3-E1 cells. It is not known if the reduction in binding sites represents a decline in total cellular binding sites or a loss of cytosolic binding sites, the remainder being associated with the cell nuclei. In either case, the ligand-occupied progestin receptors are processed differently within the two cell types.

In the present studies, the steroid-induced changes in the progestin binding site concentrations suggest that while osteoblasts do respond to estrogens and progestins, the responses are smaller and slower to occur than commonly observed in other steroid-responsive tissues. During the reproductive cycle, the normal variations in estrogen and progestin levels have pronounced acute effects on many steroid target tissues such as the uterus and breast. Bone formation is also under the influence of estrogen and progesterone as shown by cyclical changes in biochemical markers of bone formation during the menstrual cycle (Nielson et al. 1990, Gorai et al. 1998). Unlike reproductive tissues, an exceedingly rapid response to changes in circulating steroid concentrations may not be necessary for the osteoblasts to optimally serve their function.

\section{References}

Abdalla HI, Hart DM, Lindsay R, Leggate I \& Alister H 1985 Prevention of bone mineral loss in postmenopausal women by norethindrone. Obstetrics and Gynecology 66 789-792.

Al-Khouri H \& Greenstein BD 1985 Progesterone receptors in rat brain and uterus: dependence on the hormonal milieu. Journal of Endocrinology 107 159-162. 
Allegra JC, Korat O, Do HMT \& Lippman M 1981 The regulation of progesterone receptor by $17 \beta$ estradiol and tamoxifen in the ZR-75-1 human breast cancer cell line in defined medium. Journal of Receptor Research 2 17-27.

Benz DJ, Haussler MR \& Komm BS 1991 Estrogen binding and estrogenic responses in normal human osteoblast-like cells. Journal of Bone and Mineral Research 6 531-541.

Christiansen C, Nilas L, Riis BJ, Rodbro P \& Deftos LJ 1985 Uncoupling of bone formation and resorption by combined oestrogen and progestogen therapy in postmenopausal osteoporosis. Lancet 2 800-801.

Clark JH, Peck EJ Jr, Markaverich BM \& Densmore CL 1989 Basic principles and measurement of steroid hormone receptors. In Hormone Action and Molecular Endocrinology, pp 1-47. Eds MR Hughes, WT Schrader \& BW O'Malley. Houston: Houston Biological Associates.

Colston KW, King RJ, Hayward J, Fraser DI, Horton MA, Stevenson JC \& Arnett TR 1989 Estrogen receptors and human bone cells: immunological studies. Journal of Bone and Mineral Research $\mathbf{4}$ 625-631.

Eriksen EF, Colvard DS, Berg NJ, Graham ML, Mann KG, Spelsberg TC \& Riggs BL 1988 Evidence of estrogen receptors in normal human osteoblast-like cells. Science 241 84-86.

Etienne MC, Fischel JL, Milano G, Formento P, Formento JL, Francoual M, Frenay M \& Namer M 1990 Steroid receptors in human osteoblast-like cells. European Journal of Cancer 26 807-810.

Faber LE, Sandmann ML \& Stavely HE 1973 Progesterone and corticosterone binding in rabbit uterine cytosols. Endocrinology 93 74-80.

Feldman HA 1972 Mathematical theory of complex ligand-binding systems at equilibrium: some methods of parameter fitting. Analytical Biochemistry 48 317-338.

Gallagher JC, Kable WT \& Goldgar D 1991 Effect of progestin therapy on cortical and trabecular bone: comparison with estrogen. American Journal of Medicine 90 171-178.

Gorai I, Taguchi Y, Chaki O, Kikuchi R, Nakayama M, Yang BC, Yokota S \& Minaguchi H 1998 Serum soluble interleukin-6 receptor and biochemical markers of bone metabolism show significant variations during the menstrual cycle. Endocrinology 83 326-332.

Harris SA, Tau R, Enger RJ, Toft DO, Riggs L \& Spelsberg TC 1995 Estrogen Response in the hFOB 119 Human fetal osteoblastic cell line stably transfected with the human estrogen receptor gene. Journal of Cellular Biochemistry 59 193-201.

Hochberg RB, Hoyte RM \& Rosner W 1985 E-17-alpha-2$\left[{ }^{125}\right.$ I] iodovinyl-19-nortestosterone: the synthesis of a gammaemitting ligand for the progesterone receptor. Endocrinology 117 2550-2552.

Horwitz KB, Wei LL, Sedlacek SM \& D'Arville CN 1985 Progestin action and progesterone receptor structure in human breast cancer: a review. Recent Progress in Hormone Research 41 249-316.

Horowitz M, Wishart J, Need AG, Morris H, Philcox J \& Nordin BEC 1987 Treatment of postmenopausal hyperparathyroidism with norethindrone. Archives of Internal Medicine 147 681-697.

Ishida Y, Tertinegg I \& Heersche JNM 1996 Progesterone and dexamethasone stimulate proliferation and differentiation of osteoprogenitors and progenitors for adipocytes and macrophages in cell populations derived from adult rat vertebrae. Journal of Bone and Mineral Research 11 921-930.

Kanatani M, Sugimoto T, Kano J, Fukase M \& Fukita T 1991 Effect of $17 \beta$-estradiol on the proliferation of osteoblastic MC3T3-E1 cells via monocytes. Biochemical and Biophysical Research Communications 178 866-870

Komm BS, Terpening CM, Benz DJ, Graeme KA, Gallegos A, Korc M, Greene GL, O’Malley BW \& Haussler MR 1988 Estrogen binding, receptor mRNA, and biologic response in osteoblast-like osteosarcoma cells. Science 241 81-84.
Lau K-H, Wang SP, Linkhart TA, Demarest KT \& Baylink DJ 1994 Picomolar norethindrone in vitro stimulates the cell proliferation and activity of a human osteosarcoma cell line and increases bone collagen synthesis without an effect on bone resorption. Journal of Bone and Mineral Research 9 695-703.

Lippman ME, Do HMT \& Hochberg RB 1981 Specific estrogen receptor binding and biological effects of 16-alpha-iodoestradiol on human breast cancer cells. Cancer Research 41 3150-3154.

MacNamara P \& Loughrey HC 1998 Progesterone receptor A and B isoform expression in human osteoblasts. Calcified Tissue International 63 39-46.

MacNamara P, O'Shaughnessy C, Manduca P \& Loughrey HC 1995 Progesterone receptors are expressed in human osteoblast-like cell lines and in primary human osteoblast cultures. Calcified Tissue International $\mathbf{5 7}$ 436-441.

Masuyama A, Ouchi Y, Sato F, Hosoi T, Nakamura T \& Orimo H 1992 Characteristics of steroid hormone receptors in cultured MC3T3-E1 osteoblastic cells and effect of steroid hormones on cell proliferation. Calcified Tissue International 51 376-381.

McNeeley SG, Schinfeld JS, Stovall TG, Ling FW \& Buxton BH 1991 Prevention of osteoporosis by medroxyprogesterone acetate in postmenopausal women. International Journal of Obstetrics and Gynecology 34 253-256.

Migliaccio S, Wetsel WC, Fox WM, Washburn TF \& Korach KS 1993 Endogenous protein kinase-C activation in osteoblast-like cells modulates responsiveness to estrogen and estrogen receptor levels. Molecular Endocrinology 7 1133-1143.

Namkung PC \& Petra PH 1981 Measurement of progesterone receptors in human breast tumors: comparison of various methods of analysis. Journal of Steroid Biochemistry 14 851-854.

Nielson HK, Brixen K, Bouillon R \& Mosekilde L 1990 Changes in biochemical markers of osteoblastic activity during the menstrual cycle. Journal of Clinical Endocrinology and Metabolism 70 14311437.

Ojasoo T, Dore JC, Gilbert J \& Raynaud JP 1988 Binding of steroids to the progestin and glucocorticoid receptors analyzed by correspondence analysis. Journal of Medicinal Chemistry 31 1160-1169.

Orwoll ES, Stribrska L, Ramsey EE \& Keenan EJ 1991 Androgen receptors in osteoblast-like cell lines. Calcified Tissue International 49 183-187.

Pensler JM, Langman CB, Radosevich JA, Maminta ML, Mangkornkanok M, Higbee R \& Molteni A 1990 Sex steroid hormone receptors in normal and dysplastic bone disorders in children. Journal of Bone and Mineral Research 5 493-498.

Prior JC 1990 Progesterone as a bone-tropic hormone. Endocrine Reviews 11 386-398.

Renoir JM, Radanyi C, Faber LE \& Baulieu EE 1990 The nonDNA-binding heterooligomeric form of mammalian steroid hormone receptors contains a hsp90-bound 59-kilodalton protein. Journal of Biological Chemistry 265 10740-10745.

Scatchard D 1949 The attraction of proteins for small molecules and ions. Annals of the New York Academy of Sciences 51 660-672.

Schneider SL, Pontes JE, Greco JM, Murphy GP \& Sandberg AA 1984 Characterization of 7-8S progestin binding protein in human prostate using a vertical tube rotor. Journal of Steroid Biochemistry 20 715-723.

Slootweg MC, Ederveen AGH, Schot LPC, Schoonen WGEJ \& Kloosterboer HJ 1992 Oestrogen and progestogen synergistically stimulate human and rat osteoblast proliferation. Journal of Endocrinology 133 R5-R8.

Sturdee DW 1997 Newer HRT regimes. British Journal of Obstetrics and Gynaecology 104 1109-1115.

Tai PKK, Maeda Y, Nakao K, Wakim NG, Duhring JL \& Faber LE 1986 A 59-kilodalton protein associated with progestin, estrogen, androgen and glucocorticoid receptors. Biochemistry $\mathbf{2 5}$ $5269-5275$ 
Tremollieres FA, Strong DD, Baylink DJ \& Mohan S 1992 Progesterone and promegestrone stimulate human bone cell proliferation and insulin-like growth factor-2 production. Acta Endocrinologica 126 329-337.

Truss M \& Beato M 1993 Steroid hormone receptors: interaction with deoxyribonucleic acid and transcription factors. Endocrine Reviews $\mathbf{1 4}$ 459-479.

Van den Berg HW, Martin J \& Lynch M 1990 High progesterone receptor concentration in a variant of the ZR-75-1 human breast cancer cell line adapted to growth in oestrogen free conditions. British Journal of Cancer 61 504-507.

Van der Walt LA, Sanfilippo JS, Siegal JE \& Wittliff JL 1986 Estrogen and progestin receptors in human uterus: reference ranges of clinical conditions. Clinical Physiology and Biochemistry 4 217-228.
Verhaar HJJ, Damen CA, Duursma SA \& Scheven BAA 1994 A comparison of the action of progestins and estrogen on the growth and differentiation of normal adult human osteoblast-like cells in vitro. Bone 15 307-311.

Watts CKW, Parker MG \& King RJB 1989 Stable transfection of the oestrogen receptor gene into a human osteosarcoma cell line. Journal of Steroid Biochemistry 34 483-490.

Wei LL, Leach MW, Miner RS \& Demers LM 1993 Evidence for progesterone receptors in human osteoblast-like cells. Biochemical and Biophysical Research Communications 195 525-532.

Received 31 December 1998

Accepted 26 May 1999 